\title{
Peningkatan Kapasitas Pelaporan Keuangan Bumdesa Gesang Sejahtera Desa Gesang Kecamatan Tempeh Kabupaten Lumajang
}

\author{
Moh. Hudi Setyobakti \\ STIE Widya Gama Lumajang \\ Email: hudisetyobakti@gmail.com
}

\begin{abstract}
ABSTRAK
Badan Usaha Unit Desa atau Bumdesa merupakan amanat UU No. 6 Tahun 2014 tentang Desa. Pendirian BUMDesa adalah sebagai upaya menampung seluruh kegiatan di bidang ekonomi dan/atau pelayanan umum yang dikelola oleh desa dan/atau kerjasama antar desa. Pengaturan tentang BUMDesa diatur melalui Peraturan Desa. Bumdesa Gesang Sejahtera didirikan pada tahun 2017, dengan payung hukum peraturan desa. Usaha yang dikembangkan oleh Bumdesa berbasis pada potensi pertanian dan sektor lain yang sudah menjadi embrio sebelumnya. Usaha yang dikelola oleh Bumdesa meliputi; (1) pertanian dengan usaha produksi beras organik dan pupuk, obat pertanian organik, (2) jasa pengangkutan sampah, (3) pelayanan pemakaian air HIPPA. Permasalahan yang dihadapi oleh Bumdesa Gesang sejahtera sebagai mitra adalah belum optimalnya pengelolaan keuangan Bumdesa, yang terdiri dari perencanaan, pelaksanaan, penatausahaan dan pertanggungjawaban keuangan. Persoalan yang mendesak adalah penatausahaan keuangan, dimana Bumdesa belum dapat menyajikan laporan keuangan dan melaporkan kepada Pemerintah Desa. Pengabdian yang dilakukan, adalah kegiatan pelatihan dan pendampingan tentang (1) standarisasi format keuangan, (2) proses penyusunan laporan keuangan, (3) OJT menyusun laporan keuangan. Keluaran pengabdian ini adalah kemampuan pengelolaan bagi pelaksana operasional dalam proses penatausahaan dan pelaporan keuangan Bumdesa meliputi aspek kognitif, psikomotorik dan afektif.
\end{abstract}

\section{Kata Kunci : Keuangan Bumdesa, Pelatihan, Pendampingan}

\section{ABSTRACT}

Business Unit of Village Unit or Bumdesa is mandate of Law no. 6 Year 2014 on the Village. The establishment of BUMDesa is an effort to accommodate all activities in the field of economy and / or public services managed by the village and / or inter-village cooperation. The regulation on BUMDesa is regulated through Village Regulations. Bumdesa Gesang Sejahtera was established in 2017, with a legal umbrella of village law. The effort developed by Bumdesa is based on the potential of agriculture and other sectors that have become embryos before. Businesses managed by Bumdesa include; (1) agriculture with organic rice production and fertilizer business, organic agricultural medicine, (2) waste transportation services, (3) HIPPA water service. The problem faced by Bumdesa Gesang Sejahtera as a partner is not yet optimal financial management Bumdesa, which consists of planning, implementation, administration and financial accountability. The pressing issue is financial administration, where Bumdesa has not been able to present financial reports and report to the Village Government. Devotion is done, is training and mentoring activities on (1) standardization of financial format, (2) process of preparation of financial statement, (3) OJT prepare financial report. The output of this devotion is the management capability for the operational operators in the process of administration and financial reporting Bumdesa covers the aspects of cognitive, psychomotor and affective.

Keywords: Bumdesa Finance, Training, Assistance 


\section{PENDAHULUAN}

\section{A. Analisis Situasi Mitra Pengabdian}

Pembangunan dan pengembangan ekonomi di Perdesaan sudah semenjak lama dijalankan oleh Pemerintah melalui berbagai program. Salah satu program yang diharapkan mampu mendorong dan menggerakkan roda perekonomian di Perdesaan adalah melalui pendirian kelembagaan ekonomi yang dikelola sepenuhnya oleh masyarakat Desa. Lembaga ekonomi ini diharapkan juga dapat meningkatkan standar hidup ekonomi masyarakat. Salah satu fungsi Lembaga ekonomi ini yaitu menumbuh suburkan kegiatan pelaku ekonomi di Perdesaan. Bentuk kelembagaan yang dimaksud adalah Badan Usaha Milik Desa (BUMDesa).

Badan usaha ini sesungguhnya telah diamanatkan dalam UU No. 6 Tahun 2014 tentang Desa yang dijabarkan lebih lanjut dalam Peraturan Menteri Desa, PDT dan Transmigrasi Nomor 4 Tahun 2015 tentang Pendirian, Pengurusan dan Pengelolaan, Dan Pembubaran Badan Usaha Milik Desa (BUMDES).

Sebagaimana ketentuan yang termaktub dalam Peraturan Menteri Desa, PDT dan Transmigrasi tersebut bahwa maksud pendirian BUMDesa adalah sebagai upaya menampung seluruh kegiatan di bidang ekonomi dan/atau pelayanan umum yang dikelola oleh desa dan/atau kerjasama antar desa. Sedangkan tujuan pendirian BUMDesa antara lain untuk peningkatan Pendapatan Asli Desa (PA Desa), oleh karenanya dalam rangka pengembangan perekonomian Desa dan pengolahan berbagai potensi yang dimilikinya, Desa dapat membentuk BUMDesa.

BUMDesa merupakan suatu lembaga perekonomian Desa yang memiliki peranan penting dalam mewujudkan kesejahteraan masyarakat, Desa dan Pemerintah Desa. Dengan demikian kegiatan ekonomi Badan Usaha Milik Desa secara ideal merupakan bagian dari usaha peningkatan ekonomi lokal dan regional dalam lingkup perekonomian Nasional. Sejalan dengan hal tersebut, dalam perkembangannya pengaturan tentang BUMDesa harus diatur tersendiri melalui Peraturan Desa dengan merujuk pada peraturan-peraturan yang ada di atasnya.

Pengembangan BUMDes merupakan bentuk penguatan terhadap lembaga-lembaga ekonomi desa serta merupakan alat pendayagunaan ekonomi lokal dengan berbagai ragam jenis potensi yang ada di desa. BUMDes menjadi tulang punggung perekonomian pemerintahan desa guna mencapai peningkatan kesejahteraan warganya.

Desa Gesang merupakan sebuah desa yang terletak di Kecamatan tempeh Kabupaten Lumajang. Mata pencaharian penduduk mayoritas adalah petani dan sebagian lainnya pengrajin, pedagang dan profesi lainnya. Pertanian di Desa Gesang memang menjadi potensi sumber daya alam yang utama dalam menopang ekonomi warga. Tercatat ada 255 hektar lahan pertanian produktif yang berada di Desa Gesang (http://desagesang.blogspot.co.id/2017/08/profil-desa-gesang.html). Lahan pertanian yang mudah dengan pengairan, menjadikan penduduk Desa Gesang banyak yang memilih berpencaharian petani padi dan sejenisnya. 
Potret Desa dengan basis pertanian inilah yang memberikan inspirasi bagi Pemerintah Desa Gesang untuk mengoptimalkan sebagai motor penggerak perekonomian desa, dengan mendirikan Badan Usaha Milik Desa atau Bumdesa, dengan nama Bumdesa Gesang Sejahtera.

Bumdesa Gesang Sejahtera didirikan pada tahun 2017, dengan payung hukum peraturan desa. Pendirian Bumdesa didasari oleh adanya kesadaran kritis pemerintah Desa dalam upaya menggerakan roda ekonomi desa. Usaha yang dikembangkan oleh Bumdesa berbasis pada potensi pertanian dan sektor lain yang sudah menjadi embrio sebelumnya. Saat ini usaha yang dikelola oleh Bumdesa meliputi; (1) usaha bidang pertanian dengan usaha produksi beras organik dan pupuk, obat pertanian organik, (2) usaha dibidang jasa pengangkutan sampah, (3) usaha di bidang pelayanan pemakaian air melalui HIPPA.

Secara organisatoris, Bumdesa dilaksanakan oleh kepengurusan dengan struktur adanya Pembina dalam hal ini Kepala Desa, Pelaksana Operasional terdiri atas Direktur dan jajarannya serta pengawas. Berdasarkan Peraturan Pemerintah atau PP nomor 43 yang diubah dengan PP nomor 47 tahun 2015 tentang pedoman pelaksanaan UU nomor 6 tahun 2014, dalam salah satu pasal menjelaskan bahwa pengelolaan Bumdesa terpisah dari pemerintahan desa, artinya bahwa Bumdesa sebagai entitas ekonomi harus dikelola secara profesional dan akuntabel. Peraturan Permendesa nomor 4 tahun 2015 tentang Bumdesa, dan diperkuat dalam peraturan Bupati Lumajang nomor 26 tahun 2015, yang mengatur secara teknis tentang pengelolaan Bumdesa, menjelaskan bahwa Bumdesa harus dikelola secara mandiri dan bertanggungjawab.

Berkaitan dengan akuntabilitas Bumdesa, maka dalam pengelolaannya, Bumdesa dituntut untuk dapat melakukan pengelolaan secara profesional dan bertanggungjawab. Salah satu aspek penting dalam pengelolaan Bumdesa adalah pengelolaan keuangan Bumdesa, yang terdiri dari perencanaan, pelaksanaan, penatausahaan dan pertanggungjawaban keuangan. Secara khusus, penatausahaan keuangan, Bumdesa harus bisa membuat laporan keuangan dan melaporkan kepada Pemerintah Desa.

Berdasarkan latar belakang sebagaimana uraian sebelumnya, maka perlu dilaksanakan peningkatan kapasitas kepada pengelola operasional Bumdesa Sejahtera Desa Gesang agar dapat menyusun laporan keuangan yang memadai dan akuntabel, sehingga Bumdesa semakin dapat dipercaya oleh Pemerintah Desa, masyarakat dan para pihak berkepentingan lainnya.

\section{B. Permasalahan Mitra}

Bumdesa Gesang Sejahtera Desa Gesang yang baru terbentuk pada tahun 2017 dapat dikatakan relatif belum mempunyai pengalaman cukup dalam fungsi pengelolaan. Kapasitas pengelola secara syarat pendidikan akademik sudah memenuhi, karena berpendidikan SLTA dan Sarjana S1, khususnya bagian pembukuan berpendidikan SLTA tetapi tidak linier dengan kebutuhan keahlian pembukuan. Keadaan ini yang membuat pengelola Bumdesa belum bisa menyampaikan laporan pembukuan keuangan kepada Pemerintah Desa. Secara rinci, beberapa permasalahan Mitra dalam bidang pengelolaan keuangan diantaranya; 
a. Pelaksana operasional khususnya bagian pembukuan, belum mempunyai kecakapan memadai dalam penyusunan laporan keuangan.

b. Pelaksana operasional belum mendapatkan pelatihan dan pendampingan tentang pembukuan secara berkelanjutan sampai dengan mandiri dalam menyusun laporan.

c. Bumdesa belum memiliki standard baku tentang pedoman keuangan diantaranya format laporan keuangan.

\section{Solusi yang ditawarkan}

Berdasarkan uraian permasalahan pada bab sebelumnya, maka beberapa solusi yang perlu diberikan diantaranya adalah;

a. Memberikan penguatan dengan proses pelatihan dan pendampingan tentang penyusunan pedoman pengelolaan keuangan dengan diawali dari standarisasi format dengan basis sesuai alur akuntansi.

b. Memberikan pelatihan teknis tentang proses penyusunan pembukuan dari awal transaksi sampai dengan penyusunan laporan keuangan

c. Memberikan pendampingan dalam menyusun laporan keuangan berdasarkan transaksi yang telah dilakukan secara akuntabel.

\section{Target Luaran}

Mencermati atas permasalahan dan solusi yang perlu dilakukan, maka target luaran dari kegiatan pengabdian ini adalah;

a. Pelaksana operasional Bumdesa dapat memahami tentang konsep pelaporan keuangan, siklus akuntansi dan format standard berbasis akuntansi keuangan sesuai dengan jenis usaha Bumdesa.

b. Pelaksana operasional Bumdesa dapat menerapkan dan trampil dalam menyusun laporan keuangan.

c. Pelaksana operasional Bumdesa mempunyai sikap positif untuk secara konsisten menjalankan perannya dalam menyusun pembukuan secara kontinyu dan melaporkan kepada pihak pihak yang membutuhkan baik secara internal maupun eksternal.

d. Jajaran manajerial dapat membaca dan memahami laporan keuangan, serta menindaklanjuti laporan keuangan yang tersusun untuk dijadikan dasar pengambilan kebijakan manajemen maupun untuk dilaporkan kepada pemerintah desa.

e. Adanya modul pelatihan akuntansi sederhana bagi pengelola Bumdesa yang dijadikan rujukan bagi penguatan Bumdesa yang ada di kabupaten Lumajang khususnya maupun di luar kabupaten Lumajang.

f. Publikasi dalam bentuk jurnal pengabdian yang telah dilaksanakan

\section{METODE PELAKSANAAN}

Metode pelaksanaan dalam kegiatan pengabdian ini dilaksanakan dengan tahapan sebagaimana berikut;

1. Input Kegiatan 
a. Sebelum kegiatan dimulai, terlebih dahulu dilakukan penjajagan kerjasama dan kesediaan mitra untuk dilaksanakan pengabdian.

b. Penilaian kebutuhan dilakukan untuk mendapatkan informasi riil tentang kebutuhan mitra, berdasarkan analisis situasi dan permasalahan yang dihadapi mitra, khususnya terkait dengan permasalahan pembukuan Bumdesa

c. Menyiapkan modul latih

2. Proses Pelaksanaan

a. Pelaksanaan kegiatan ini dilakukan dengan memberikan pelatihan model clasical in class dengan metode focus group discussion (FGD) dalam 2 (dua) tahap.

b. Pasca kegiatan pelatihan clasical dilaksanakan praktikum langsung atau On The Jobs Training.

c. Pendampingan diberikan baik secara langsung dengan mengunjungi mitra maupun tidak langsung, dengan fokus bimbingan pembukuan.

a. Keluaran

a. Keluaran langsung

1) Pelaksana operasional memahami secara konsep

2) Pelaksana operasional terampil dalam membukukan keuangan

3) Adanya standard pembukuan yang menjadi acuan pelaksanaan

b. Keluaran lanjutan

1) Adanya sikap positif dari pelaksana operasional untuk secara konsisten menyusun pembukuan dan melaporkan secara rutin.

2) Laporan keuangan yang akuntabel

3) Modul latih pembukuan sederhana bagi Bumdesa

4) Publikasi dalam bentuk artikel pada jurnal pengabdian

b. Monitoring dan evaluasi

Kegiatan monitoring dilaksanakan untuk memastikan bahwa kegiatan yang dilaksanakan telah berjalan sesuai dengan skema yang dibuat. Monitoring dilaksanakan pada saat penyiapan input sampai dengan pelaksanaan. Proses monitoring dilaksnaakan secara langsung dengan pengamatan.

Evaluasi dilakukan pada seluruh tahapan setelah tahapan tersebut dilalui. Evaluasi bertujuan untuk melakukan perbaikan perbaikan sehingga bisa meningkatkan kualitas pelaksanan pengabdian baik kepada mitra maupun calon mitra lainnya.

Berikut adalah bagan kerangka pelaksanaan pengabdian masyarakat pada Bumdesa Gesang Sejahtera. 
Gambar 1

Metode pelaksanaan

\begin{tabular}{|c|c|c|c|}
\hline INPUT & PROSES & OUTPUT & OUTCOME \\
\hline $\begin{array}{l}\text { 1. Kesepakatan } \\
\text { kerjasama } \\
\text { pengabdian } \\
\text { 2. Penilaian } \\
\text { Kebutuhan } \\
\text { 3. Penyiapan } \\
\text { Modul }\end{array}$ & $\begin{array}{l}\text { 1. Implementasi } \\
\text { Pelatihan } \\
\text { 2. On The Job } \\
\text { Training } \\
\text { 3. Pendampingan }\end{array}$ & $\begin{array}{l}\text { 1. Kognitif } \\
\text { 2. Psikomotorik }\end{array}$ & $\begin{array}{l}\text { 1. Afektif } \\
\text { 2. Laporan } \\
\text { Kontinyu } \\
\text { 3. Laporan } \\
\text { Akuntabel } \\
\text { 4. Modul } \\
\text { Standard }\end{array}$ \\
\hline
\end{tabular}

\section{MONITORING dan EVALUASI}

\section{JADWAL KEGIATAN}

Pelaksanaan pengabdian masyarakat ini, dilaksanakan selama 2 (dua) bulan, mulai dari penyiapan input sampai dengan pelaksanaan.

Tabel 1

Jadwal Pelaksanaan

\begin{tabular}{|l|l|l|l|l|l|l|l|l|l|}
\hline \multirow{2}{*}{ No } & \multicolumn{1}{|c|}{ Kegiatan } & \multicolumn{3}{|c|}{1} & \multicolumn{3}{|c|}{2} \\
\hline & & 1 & 2 & 3 & 4 & 1 & 2 & 3 & 4 \\
\hline & 1. Kesepakatan kerjasama pengabdian & & & & & & & & \\
\hline 2. Penilaian Kebutuhan & & & & & & & & \\
\hline 3. Penyiapan Modul & & & & & & & & \\
\hline 4. Implementasi Pelatihan & & & & & & & & \\
\hline 5. On The Job Training & & & & & & & & \\
\hline 6. Pendampingan & & & & & & & & \\
\hline 7. Monev & & & & & & & & \\
\hline 8. Pelaporan & & & & & & & & \\
\hline 9. Publikasi & & & & & & & & \\
\hline
\end{tabular}

\section{PELAKSANAAN}

\section{Mitra Kegiatan}

Mitra kegiatan dalam pengabdian ini adalah Bumdesa Gesang Sejahtera Desa Gesang Kecamatan Tempeh kabupaten Lumajang.

\section{Waktu dan Tempat Pelaksanaan}

a. Kegiatan Persiapan

1) Penjajagan Kerjasama Pengabdian

Penjajagan ini dilaksanakan di tingkat Pemerintah Desa dan Bumdesa. Lokasi bertempat di kantor Desa Gesang. Pelaksanaan pada minggu I bulan Januari 2018.

2) Penilaian Kebutuhan

Penilaian kebutuhan dilaksanakan pada saat kunjungan di kantor Bumdesa pada minggu ke 1 Januari 2018.

3) Penyiapan Modul

Penyiapan modul dilaksanakan d STIE Widya Gama pada minggu ke 1 dan 4 di bulan Januari 2018.

b. Kegiatan Pelaksanaan

1) Pelatihan tahap awal 
Pelatihan tahap awal dengan model clasical metode FGD dilaksanakan pada minggu ke 2 bulan Januari 2018 tepatnya tanggal 14 januari 2018 di kantor Bumdesa Gesang Sejahtera.

2) Pelatihan lanjutan dan OJT

Pelatihan tahap 2 atau lanjutan dilaksnakan d kantor Bumdesa pada minggu pertama di bulan Februari tepatnya tanggal 7 Februari 2018. Proses OJT masih tetap berlangsung terutama pengisian saldo awal dan tetap menjadi rangkaan agenda pelatihan, dengan skema konsultasi jarak jauh.

3) Pendampingan

Kegiatan pendampingan diberikan sebagai bentuk penguatan pemahaman ketika ada kesulitan dalam pengerjaan pembukuan. Pendmapingan juga sebagai bagian dari kegiatan monitoring atas target luaran yang ditetapkan. Pendampingan bersifat berkelanjutan dimulai dari minggu ke 2 bulan Februari sampai Minggu ke 4 Februari 2018.

5) Sasaran Kegiatan Pengabdian

Sasaran dalam kegiatan pengabdian ini adalah jajaran manajerial Bumdesa Gesang Sejahtera, yang terdiri atas Direktur, bagian Pembukuan induk dan unit serta kepala kepala unit usaha.

\section{PENUTUP}

\section{Simpulan}

Pendirian Badan Usaha Unit Desa atau Bumdesa adalah amanat UU No. 6 Tahun 2014 tentang Desa yang dijabarkan lebih lanjut dalam Peraturan Menteri Desa, PDT dan Transmigrasi Nomor 4 Tahun 2015 tentang Pendirian, Pengurusan dan Pengelolaan, Dan Pembubaran Badan Usaha Milik Desa (BUMDES). Pendirian BUMDesa adalah sebagai upaya menampung seluruh kegiatan di bidang ekonomi dan/atau pelayanan umum yang dikelola oleh desa dan/atau kerjasama antar desa. Pengaturan tentang BUMDesa diatur melalui Peraturan Desa.

Bumdesa Gesang Sejahtera didirikan pada tahun 2017, dengan payung hukum peraturan desa. Usaha yang dikembangkan oleh Bumdesa berbasis pada potensi pertanian dan sektor lain yang sudah menjadi embrio sebelumnya. Saat ini usaha yang dikelola oleh Bumdesa meliputi; (1) usaha bidang pertanian dengan usaha produksi beras organik dan pupuk, obat pertanian organik, (2) usaha dibidang jasa pengangkutan sampah, (3) usaha di bidang pelayanan pemakaian air melalui HIPPA.

Permasalahan yang dihadapi oleh mitra adalah belum optimalnya pengelolaan keuangan Bumdesa, yang terdiri dari perencanaan, pelaksanaan, penatausahaan dan pertanggungjawaban keuangan. Persoalan yang mendesak adalah penatausahaan keuangan, Bumdesa belum dapat menyajikan laporan keuangan dan melaporkan kepada Pemerintah Desa.

Berdasarkan persoalan yang dhadapi Bumdesa Gesang Sejahtera, maka pengabdian yang dilakukan dengan mitra, dengan kegiatan pelatihan dan pendampingan tentang penyusunan (1) pedoman pengelolaan keuangan dengan diawali dari standarisasi format dengan basis sesuai alur akuntansi, (2) proses penyusunan pembukuan dari awal transaksi sampai dengan penyusunan laporan keuangan, (3) Menyusun laporan keuangan berdasarkan transaksi yang telah dilakukan secara akuntabel.

Keluaran yang dihasilkan dalam pengabdian ini adalah kemampuan pengelolaan bagi pelaksana operasional dalam proses penatausahaan dan pelaporan keuangan Bumdesa meliputi aspek kognitif, psikomotorik dan afektif.

\section{Saran}

Berdasarkan pada evaluasi atas hasil yang dicapai dalam kegiatan pengabdian, maka diperlukan langkah lanjutan sebagai rekomendasi bagi pengembangan Bumdesa ke depan, diantaranya;

a. Pelaksana operasional harus secara konsisten melanjutkan hasil pengabdian dengan menyusun laporan secara kontinyu dan menjaga kualitas laporan serta mempertanggungjawabkan kepada masyarakat melalui Pemerintah Desa.

b. Diperlukan kerjasama semua pihak, khususnya piha eksernal yang berkepentingan dengan pengembangan Bumdesa, untuk menindaklanjuti penguatan dalam hal manajemen pengelolaan dari aspek SDM, Produksi Pemasaran agar Bumdesa makin berkembang dan berkontribusi nyata bagi masyarakat dan Desa,

c. STIE Widya Gama sebagai salah satu institusi Perguruan Tinggi, diharapkan menjadikan Bumdesa Gesang Sejahtera dan Desa Gesang secara lebih luas menjadi laboratorium 
implementasi Tri Dharma Perguruan Tinggi, yang sesuai dengan bidang keilmuan STIE Widya Gama Lumajang.

\section{DAFTAR PUSTAKA}

http://desagesang.blogspot.co.id/2017/08/profil-desa-gesang.html

Permendesa nomor 4, tahun 2015 tentang Pendirian dan Pengelolaan Bumdesa

Peraturan Pemerintah nomor 43 yang di rubah dengan PP 47 tahun 2015, tentang pedoman pelaksanaan UU nomor 6 tahun 2014

Peraturan Bupati Lumajang nomor 26 tahun 2015, tentang pedoman pendirian, pengelolaan dan pembubaran Bumdesa

Undang undang nomor 6 tahun. 2014. tentang Desa 